\title{
CONTROLLED FORMATION OF Fe NANOPARTICLES IN SILICA
}

\author{
I. Šimkienè ${ }^{\text {a }}$, G.J. Babonas ${ }^{\text {a }}$, A. Rėza ${ }^{\text {a }}$, M. Baran ${ }^{\text {b }}$, R. Szymczak ${ }^{\text {b }}$ J. Sabataitytè ${ }^{\text {a }}$, \\ and A. Suchodolskis ${ }^{\mathrm{a}}$ \\ a Semiconductor Physics Institute, A. Goštauto 11, LT-01108 Vilnius, Lithuania \\ E-mail:irena@pfi.lt \\ ${ }^{\mathrm{b}}$ Institute of Physics, PAN, Al. Lotników 32/46, 02-668 Warsaw, Poland
}

Received 24 January 2006

\begin{abstract}
The $\mathrm{SiO}_{2}: \mathrm{Fe}$ films on $\mathrm{Si}$ substrates were produced by sol-gel and spinning techniques. Hybrid organic-inorganic precursor (tetraethoxysilane- $\mathrm{FeCl}_{3}$ ) and organic alkoxide precursor modified from $\mathrm{Fe}$ acetate were used. The $\mathrm{Fe}$ nanoparticles have been formed by various technological procedures. The structural, magnetic and optical characteristics of $(\mathrm{SiO} 2: \mathrm{Fe}) / \mathrm{Si}$ samples depending on technology of sample preparation were examined. The size of Fe nanoparticles was shown to be controlled by precursor preparation procedure. It was found that Fe-containing nanocrystals of average size $\sim 40 \mathrm{~nm}$ were formed by "one-pot" technique from the mixture of solutions containing Fe salts and freshly prepared colloidal tetraethoxysilane (TEOS). In contrast, in the "two-pots" procedure, the components of precursor were prepared non-simultaneously and the structurized TEOS sol was used. In the latter case, Fe nanoparticles were distributed in size over a larger range with a mean value at $\sim 25 \mathrm{~nm}$. It was hence concluded that precursor-controlled formation of Fe nanoparticles can be achieved using different sol-gel technological procedures.
\end{abstract}

Keywords: nanoscale materials and structures, fabrication and characterization

PACS: 81.07.-b, 81.16.Dn

\section{Introduction}

Recently, metal nanoparticles have attracted considerable attention because of their potential applications as optical, electronic, catalytic, and magnetic materials [1]. In particular, nanoparticles of transition metals were synthesized and intensively studied [14]. It was found that various nanoparticles of transition metals and their oxides were formed depending on technological procedure. For example, superparamagnetic particles (of 10-15 $\mathrm{nm}$ in diameter) of magnetite $\mathrm{Fe}_{3} \mathrm{O}_{4}$ coated with (3-aminopropyl)triethoxysilane $\mathrm{NH}_{2}\left(\mathrm{CH}_{2}\right)_{3} \mathrm{Si}\left(\mathrm{OC}_{2} \mathrm{H}_{5}\right)_{3}$ (APTES) were prepared by silanization reaction [2] and using chemical co-precipitation method [4]. Nanoparticles of maghemite $\gamma-\mathrm{Fe}_{2} \mathrm{O}_{3}$ were synthesized by thermal decomposition of $\mathrm{Fe}$ acetate $\mathrm{Fe}\left(\mathrm{C}_{2} \mathrm{H}_{3} \mathrm{OO}\right)_{3}$ in a solution of polyethylene at high temperature [5]. Infrared transmission spectra were usually measured [2-4] in order to determine the type of $\mathrm{Fe}$ oxide from analysis of vibration modes.

Sol-gel technique was widely used [6] to produce Fe-containing silica films of different porosity [7]. It was found [6] that magnetic and optical properties of
Fe-doped silica films were strongly dependent on technological procedure, i. e., on the preparation of precursors and post-growth thermal treatment in various ambient gases. Therefore, the actual problem is to reveal the typical regularities in the formation of metal nanoparticles and on the basis of the obtained results to develop the technique for the control the size, composition, and physical properties of self-formed precipitates.

In this work, the influence of precursor composition and precursor preparation procedure on the characteristics of Fe-containing particles in sol-gel processed silica films was studied. The $\left(\mathrm{SiO}_{2}: \mathrm{Fe}\right) / \mathrm{Si}$ samples synthesized by "one-pot" and "two-pots" technological procedures were studied by structural, magnetic, and optical measurements.

\section{Experimental}

The samples $\left(\mathrm{SiO}_{2}: \mathrm{Fe}\right) / \mathrm{Si}$ were prepared by sol-gel spin-on technique described elsewhere [6]. The precursor was made by mixing the solution of $\mathrm{Fe}$ compound with either freshly prepared colloidal tetraethoxysilane (TEOS) ethanol solution ("one-pot" reaction, l-type 


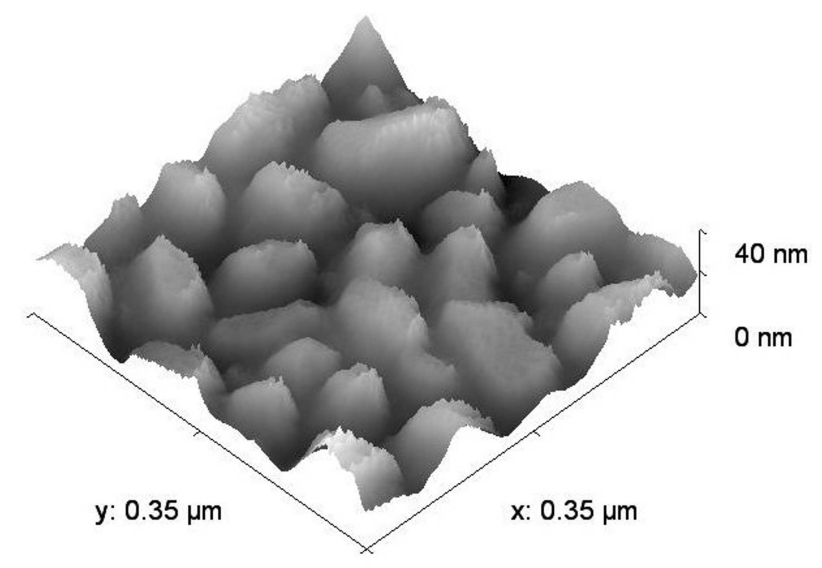

(a)

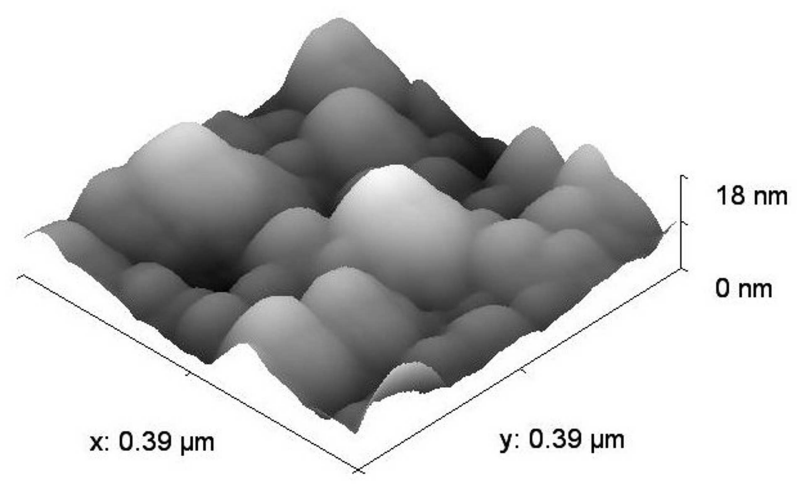

(c)

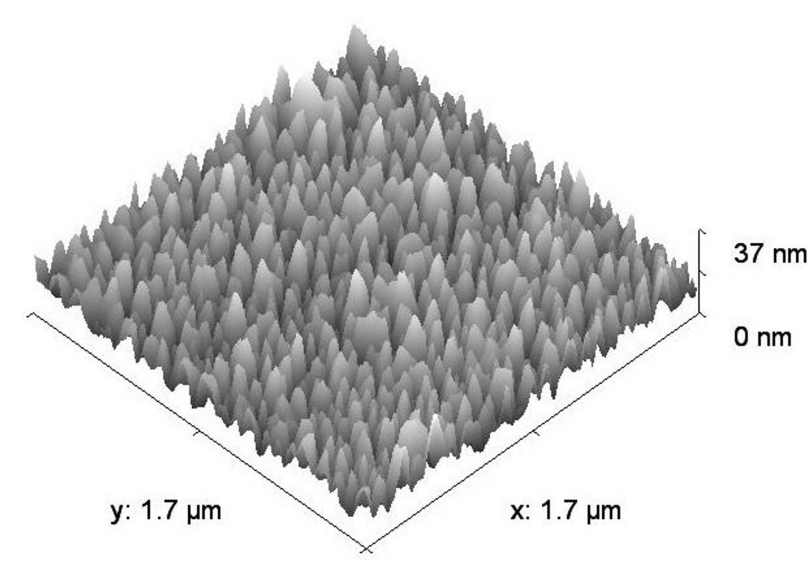

(b)

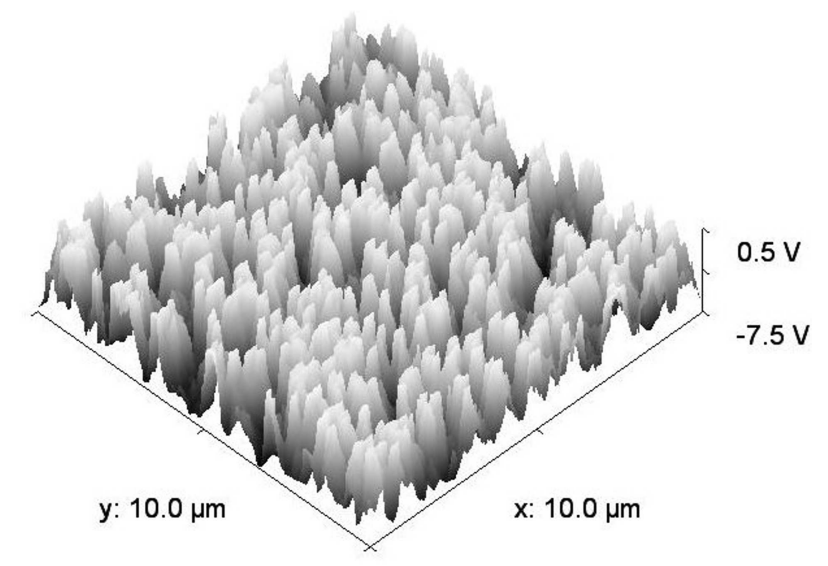

(d)

Fig. 1. (a-c) AFM and (d) SSRM micrograhs of (a,b) $1 A$-type and (c, d) $2 A$-type samples fabricated by using precursor containing $\mathrm{FeCl}_{3}$ by "one-pot" and "two-pots" techniques, respectively. In (d), an increase of voltage (increase of brightness) corresponds to a decrease of resistance.

samples) or with a structurized TEOS sol ("two-pots" reaction, 2-type samples). The colloidal TEOS solution was prepared with or without APTES, which is supposed [2] to enhance the interaction with substrate due to the presence of $\mathrm{NH}_{2}$ groups. In some series cetyltrimetylammonium bromide (CTAB) was added into sol. Fe-containing particles were formed from either colloidal solution of $\mathrm{FeCl}_{3}$ (1A-, 2A-type samples) or organic compound $\mathrm{Fe}$ acetate $(1 B-, 2 B$-type samples). Fe acetate was easily decomposed by thermal treatment. The acidity of coating solutions was in the range of $\mathrm{pH}$ values $1.9-2.1$. The coating solution was deposited on $n$-Si $(0.5 \Omega \mathrm{cm})$ wafers by spinning at $2500 \mathrm{rpm}$. The structure composed of hybrid material, i.e., Fe clusters imbedded in silica, were dried in air at $95^{\circ} \mathrm{C}$ for $0.5 \mathrm{~h}$ and annealed in $\mathrm{H}_{2}$ ambient at $550{ }^{\circ} \mathrm{C}$ for $2 \mathrm{~h}$. As it has been concluded previously [6], annealing in $\mathrm{H}_{2}$ ambient favours formation of small Fe-containing nanoparticles with prevailing composition of pure Fe.
The surface structure of hybrid layer $\left(\mathrm{SiO}_{2}: \mathrm{Fe}\right)$ on $\mathrm{Si}$ was investigated by scanning probe microscope (Digital Instruments Dimension 3100) combined with electronic block for scanning spreading resistance microscopy (SSRM) studies. For SSRM measurements [8], a conductive diamond-coated silicon probe was used. Along with SSRM, standard atomic force microscopy (AFM) measurements were performed.

Optical properties of $\mathrm{Fe}$-doped $\mathrm{SiO}_{2}$ films on $\mathrm{Si}$ were studied by spectroscopic ellipsometry. The measurements were carried out at $300 \mathrm{~K}$ in the spectral range of $1-5 \mathrm{eV}$ by means of a photometric ellipsometer with rotating analyzer. Ellipsometric parameters $\Psi$ and $\Delta$ were measured with an accuracy of $0.02^{\circ}$. Experimental data for $\mathrm{SiO}_{2}: \mathrm{Fe}$ film were analyzed in the model of multilayer structure. Each $i$ th layer was characterized by a complex dielectric function $\varepsilon_{i}$ and thickness $d_{i}$. For a composite layer consisting of a mixture of various materials and voids, the effective dielectric function $\varepsilon_{\text {eff }}$ was determined by employing the 
model of effective media. The ellipsometric parameters $\Psi$ and $\Delta$ were directly calculated by solving Maxwell equations using the transfer matrix technique. Details of the experimental set-up for spectroscopic ellipsometry measurements and fitting procedure were described elsewhere [9].

Magnetic measurements have been carried out by using a standard SQUID magnetometer MPMS-5, Quantum Design. The magnetization was measured in the temperature range of $5-300 \mathrm{~K}$ in magnetic fields up to $50 \mathrm{kOe}$.

\section{Results and discussion}

From the general considerations it follows that the microstructure of 1 - and 2-type samples should be different. In the 1-type samples, the precursor obtained at mixing of Fe-containing solution and TEOS, which have been prepared simultaneously, should be quite homogeneous on nano- scale. As a result, the formation of Fe-containing particles takes place at similar conditions within the volume of a whole precursor. In contrast, in the 2-type samples, a structurized TEOS sol probably presents a large variety of local structural sites for the self-formation of Fe-containing particles. As a result, different $\mathrm{Fe}$ particles can be formed in the latter case.

AFM studies have shown (Figs. 1, 2) that Fe-containing nanoparticles of $10-80 \mathrm{~nm}$ in diameter and 20 $40 \mathrm{~nm}$ in height were formed in both $1 A$ - and $2 A$-type samples. Nanoparticles aggregated into larger 100$200 \mathrm{~nm}$ clusters, which were conducting according to the SSRM data and hence contained Fe particles (Fig. 1). However, the difference between the two types of samples should be noticed. On the one hand, the size histogram showed (Fig. 2) that Fe nanoparticles were distributed in a larger range for 2A-type than for $1 A$-type samples. On the other hand, the histograms have shown the peaks at $40 \mathrm{~nm}$ and $25 \mathrm{~nm}$ for samples of $1 A$ - and $2 A$-type, respectively. This observation indicates the difference in the mean size of $\mathrm{Fe}$ nanoparticles depending on the technology procedure.

The regularities in the size distribution of Fe nanoparticles can be qualitatively explained by the following considerations. In "one-pot" method, the sol is more homogeneous as $\mathrm{Fe}(\mathrm{OH})_{3}$ does not aggregate and attaches to $\mathrm{Si}-\mathrm{O}-\mathrm{Si}$ polymers at hydrolysis and condensation of TEOS, which take place simultaneously during this procedure. In contrast, during the "two-pots" process, $\mathrm{Fe}(\mathrm{OH})_{3}$ is interacting with al-

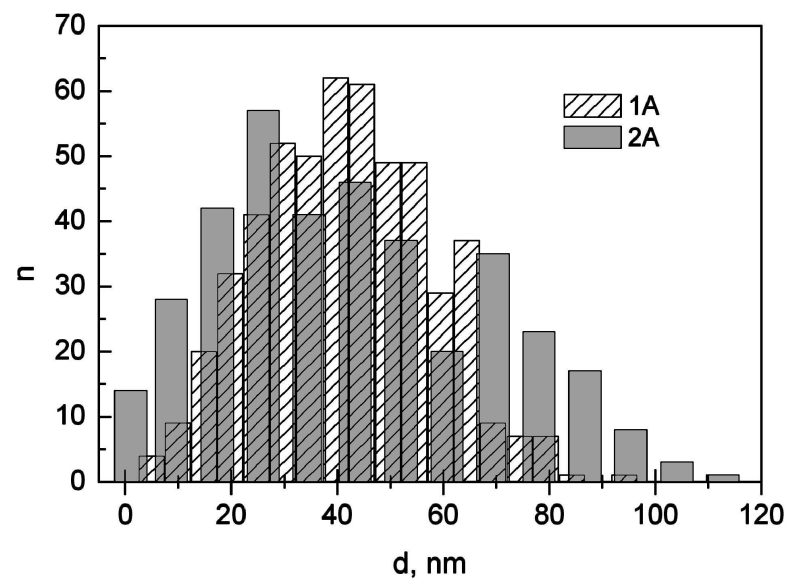

Fig. 2. Histogram of size distribution of nanoparticles in $1 A$ - and 2A-type samples obtained from AFM measurements.

ready formed structure of polymers possessing various sites for the formation of Fe nanoparticles.

The optical spectra obtained by ellipsometric measurements can be adequately interpreted taking into account the particular structural features of hybrid $\left(\mathrm{SiO}_{2}: \mathrm{Fe}\right) / \mathrm{Si}$ samples. The spectra of ellipsometric parameters $\Psi$ and $\Delta$ for studied $\left(\mathrm{SiO}_{2}: \mathrm{Fe}\right) / \mathrm{Si}$ samples are illustrated by Fig. 3. In the spectra of the first type (Fig. 3(a)), the interference pattern due to the presence of Fe-doped silica film was observed. This interpretation was based on observation of a typical interference feature - an abrupt phase change in the $\Delta$ spectra due to the reflection from the interface film-substrate. Manifestation of the first type spectrum indicated that $\mathrm{Fe}$-doped silica film was quite transparent and homogeneous in both lateral plane and in the direction of surface normal. In this case, a weak absorption was caused by a small amount of $\mathrm{Fe} / \mathrm{Fe}$ oxide in silica film. The spectra of the second type (Fig. 3(b)) did not show an interference pattern. A strong absorption and nonhomogeneity of Fe-doped silica film could be possible reasons for suppression of interference effects.

The adequate model for interpretation of experimental data was constructed in the multi-layer structure making use of reference data for dielectric function of $\mathrm{SiO}_{2}$ [10], bulk $\mathrm{Fe}$ [11], and $\mathrm{Fe}$ oxides $\mathrm{Fe}_{2} \mathrm{O}_{3}$ [12] and $\mathrm{Fe}_{3} \mathrm{O}_{4}$ [13]. The effective dielectric function $\varepsilon_{\text {eff }}$ of the Fe-doped silica film was determined in terms of the effective media model [14], combining the relative contributions of materials and voids. In the case of strongly absorbed Fe-doped silica films (Fig. 3(b)), $\varepsilon_{\text {eff }}$ was simulated by Lorentzian-type lines.

The spectra of ellipsometric parameters were quite similar for hybrid samples prepared from $\mathrm{FeCl}_{3}$ by "one-pot" (1A-type) and "two-pots" ( $2 A$-type) techniques. The corresponding spectra of effective dielec- 


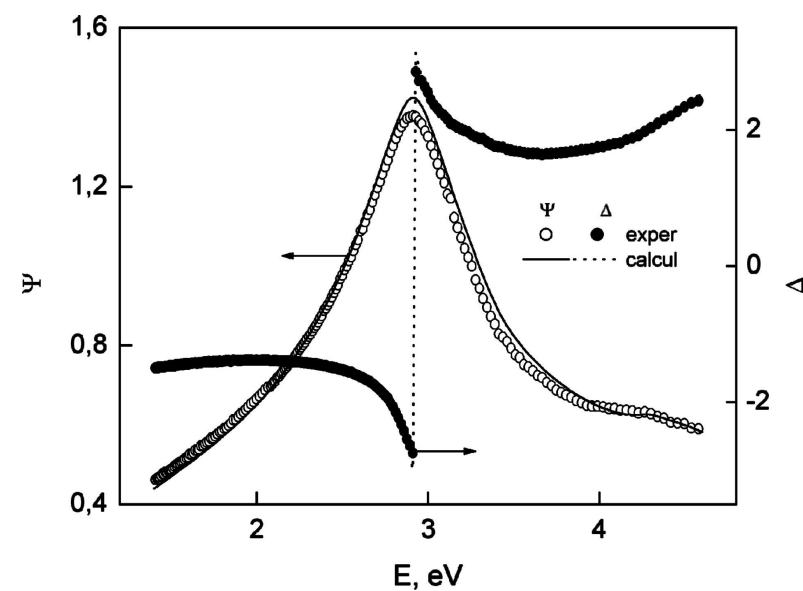

(a)

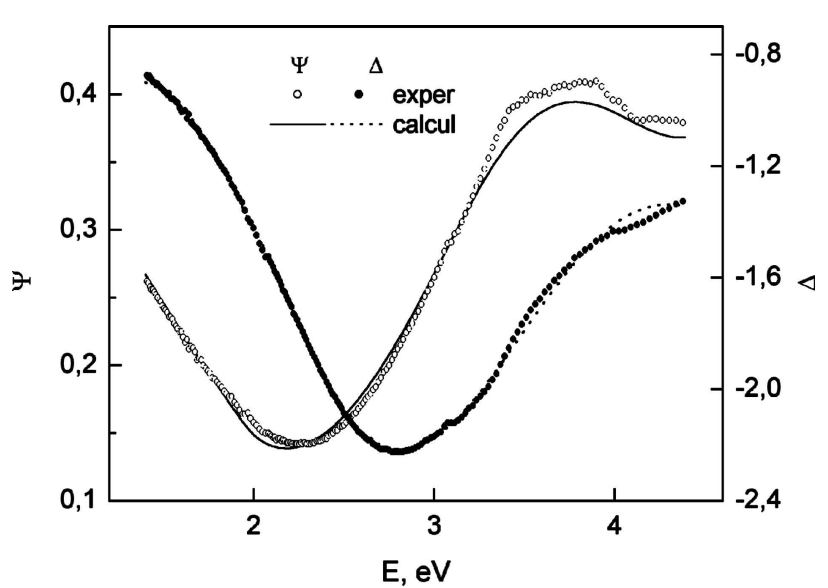

(b)

Fig. 3. Experimental (points) and simulated (curves) spectra of the ellipsometric parameters $\Psi$ and $\Delta$ for $\left(\mathrm{SiO}_{2}: \mathrm{Fe}\right) / \mathrm{Si}$ samples produced by "one-pot" technique from precursor containing (a) Fe acetate together with CTAB ( $1 B$-type sample) and (b) $\mathrm{FeCl}_{3}(1 A$-type sample).

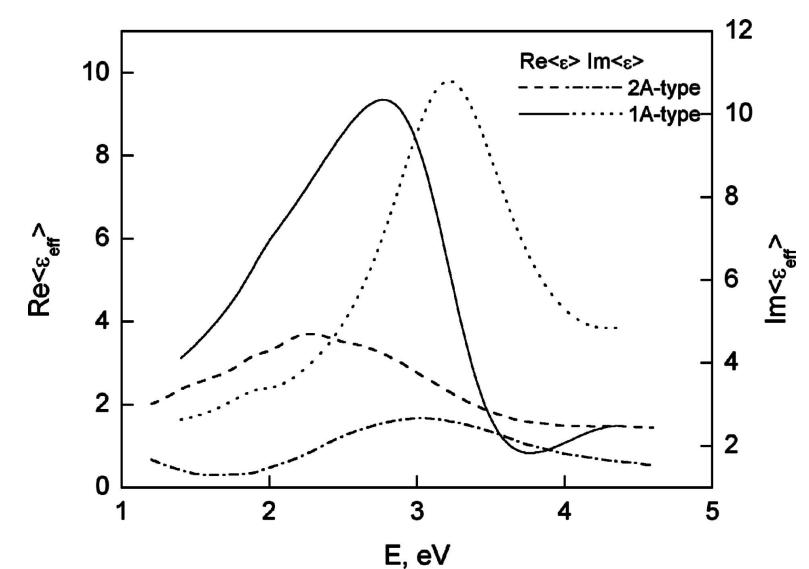

Fig. 4. Spectra of effective dielectric function $\left\langle\varepsilon_{\text {eff }}\right\rangle$ of Fe-doped silica film obtained by fitting the simulated results to experimental data for $1 A$ - and $2 A$-type samples.

tric function $\left\langle\varepsilon_{\text {eff }}\right\rangle$ (E) (Fig. 4) for $\mathrm{SiO}_{2}: \mathrm{Fe}$ film has shown the main peak at $\sim 3.2 \mathrm{eV}$. The latter value could be compared with those for $\mathrm{Fe}_{2} \mathrm{O}_{3}$ [12] and $\mathrm{Fe}_{3} \mathrm{O}_{4}$ [14]. The optical features of $\mathrm{SiO}_{2}: \mathrm{Fe}$ film at $\sim 2 \mathrm{eV}$ corresponded to those for $\mathrm{Fe}$ [11] or $\mathrm{Fe}_{3} \mathrm{O}_{4}$. The main peak in the spectrum of $\left\langle\varepsilon_{\text {eff }}\right\rangle$ (E) for $2 A$-type sample was broader and of a smaller intensity as compared to that for 1A-type samples. This observation is in agreement with structural data (Fig. 2): the size of Fe nanoparticles were distributed over a larger range leading to a broadening of optical features.

On the other hand, the fine structure of the $\left\langle\varepsilon_{\text {eff }}\right\rangle(E)$ spectra can also be contributed by the plasma resonance in Fe nanoparticles. As it is known [15], quantum size effects lead to an increase of the plasma energy in metal nanoparticles. In addition, the presence of metal nanoparticles of various sizes is resulting in a broadening of plasma peak and occurrence of addi- tional structure. This is in qualitative agreement with the data presented in Fig. 4.

The magnetic properties of the $1 A$ - and $2 A$-type samples [16] were also similar. The saturation of magnetization $\mathrm{M}_{\mathrm{Fe}} \sim 1.5 \mu_{\mathrm{B}}$ was achieved for both type samples in a magnetic field of about $3 \mathrm{kOe}$. However, a difference in high field behaviour was found: for $2 A$-type sample, there was practically no change of $\mathrm{M}_{\mathrm{Fe}} \sim 1.61 \pm 0.025 \mu_{\mathrm{B}}$ at higher fields, whereas for 1A-type sample the $\mathrm{M}_{\mathrm{Fe}}$ value gradually grew from 1.34 to $1.46 \mu_{\mathrm{B}}$. The difference was also noticed [16] in the width of hysteresis loops and in temperature dependence of magnetization. These observations could suggest [16] that there was a stronger frustration of magnetic moments in $\mathrm{Fe}$ clusters / particles in the 1A-type samples. In the case of $2 A$-type sample, the dimensions of Fe particles/clusters were widely distributed with a part of these being smaller than those in 1A-type sample, in agreement with structural and optical data.

A remarkable difference was observed between the physical properties of Fe-doped films produced by "one-pot" technique from $\mathrm{FeCl}_{3}$ (1A-type sample) and $\mathrm{Fe}$ acetate ( $1 B$-type sample) with surfactant CTAB. A smooth $\mathrm{SiO}_{2}$ :Fe layer was formed in $1 B$-type sample whereas large defects of size up to $10 \mu \mathrm{m}$ were observed in $1 A$-type sample. In the optical response of $1 B$-type sample the interference pattern (Fig. 3(a)) dominated. Analysis of experimental $\Phi$ and $\Delta$ spectra has shown that a small amount of $\mathrm{Fe}(\sim 1 \%)$ should be taken into account. However, the Fe nanoparticles were distributed non-homogeneously in depth. The simulated $\Phi$ and $\Delta$ spectra fitted the experimental ones in the model of three porous Fe-doped silica layers. It is reasonable to assume that small dispersed 
Fe-containing nanoparticles were formed from precursor with $\mathrm{Fe}$ acetate. On the other hand, as followed from SSRM studies, in the $1 A$-type sample smaller clusters $(<500 \mathrm{~nm})$ of conducting nanoparticles were formed whereas large defects were non-conductive.

The optical response of the samples prepared from Fe-acetate-containing precursor with or without APTES was similar. In both cases the interference pattern was observed in the spectra of ellipsometric parameters and the contribution of $\mathrm{Fe}_{2} \mathrm{O}_{3}$ in amount of $1-2 \%$ in silica has to be taken into account in calculated spectra to fit the experimental data. In the spectra of $\left\langle\varepsilon_{\text {eff }}\right\rangle$ for $\mathrm{Fe}$-doped silica film the maximum was revealed at 2.3 and $2.7 \mathrm{eV}$ for samples grown from precursors with and without APTES, respectively. This difference could be caused by the surface modification of $\mathrm{Fe}$-containing nanoparticles [4].

The Fe-doped silica layer was thicker for the sample prepared with APTES because of the presence of reactive $\mathrm{NH}_{2}$ groups resulting in an increase of the density of coating solution and a stronger interaction of Fe-doped silica film with Si substrate. Small nanoparticles of $10 \mathrm{~nm}$ size and $4-6 \mathrm{~nm}$ height were observed by AFM in the samples produced from precursors without APTES.

\section{Summary}

Silica Fe-doped films on $\mathrm{Si}$ substrates were fabricated by sol-gel spin-on technique and characterized by structural, optical, and magnetic properties. It was determined that the size of Fe-containing particles could be controlled by the procedure of precursor preparation. On the one hand, in the "one-pot" technique, during which the components of precursor were prepared simultaneously, the silica films contained larger $\mathrm{Fe}$ nanoparticles distributed over a relatively narrow range of sizes. On the other hand, in the "two-pots" technique, in which a structurized sol was used, the average size of Fe nanoparticles was smaller but the distribution range of sizes was wider. Using the precursor with APTES, thicker Fe-doped silica films were fabricated due to an increased interaction of coating solution with substrate.

\section{Acknowledgement}

Support from the EU project PHOREMOST (No. 511616) is gratefully acknowledged.

\section{References}

[1] P. Tartaj, M. del Puerto Morales, S. VeintemillasVerdaguer, T. Gonzalez-Carreno, and C.J. Serna, J. Phys. D 36, R182-R197 (2003).

[2] M. Yamaura, R.L. Camilo, L.C. Sampaio, M.A. Macedo, M. Nakamura, and H.E. Toma, J. Magn. Magn. Mater. 279, 210-217 (2004).

[3] S.-H. Wu and D.-H. Chen, Chem. Lett. 33, 406-407 (2004).

[4] X.-C. Shen, X.-Z. Fang, Y.-H. Zhou, and H. Liang, Chem. Lett. 33, 1468-1469 (2004).

[5] G.Y. Yurkov, S.P. Gubin, D.A. Pankratov, Y.A. Koksharov, A.V. Kozinkin, Y.I. Spichkin, T.I. Nedoseikina, I.V. Pirog, and V.G. Vlasenko, Inorg. Mater. 38, 137145 (2002).

[6] I. Simkiene, J. Sabataityte, J.G. Babonas, A. Reza, R. Szymczak, H. Szymczak, M. Baran, M. Kozlowski, and S. Gierlotka, Proc. SPIE 5946, OH-1OH-6 (2005).

[7] I. Simkiene, M. Baran, G.-J. Babonas, R.-A. Bendorius, A. Reza, R. Szymczak, P. Aleshkevych, R. Sustaviciute, and R. Tamasevicius, Acta Phys. Pol. A 107, 400-407 (2005).

[8] P. De Wolf, J. Snauwert, L. Hellemans, T. Clarysse, W. Vandervorst, M. D'Olieslaeger, and D. Quaeyhaegens, J. Vac. Sci. Technol. A 13, 1699-1704 (1995).

[9] G.J. Babonas, A. Niilisk, A. Reza, A. Matulis, and A. Rosental, Proc. SPIE 5122, 50-55 (2002).

[10] C.M. Herzinger, B. Johns, W.A. McGaham, J.A. Woollam, and W. Paulson, J. Appl. Phys. 83, 3323-3336 (1998).

[11] C.L. Foiles, in: Landolt-Börnstein: Numerical Data and Functional Relationships in Science and Technology - New Series, Vol. 15b, eds. K.-H. Hellwege and J.L. Olsen (Springer-Verlag, Berlin, 1985).

[12] P. Ruzakowski Athey, M.F. Tabet, and F.K. Urban, J. Vac. Sci. Technol. A 15, 998-1006 (1997).

[13] G.A. Niklasson and C.G. Granquist, J. Appl. Phys. 55, 3382-3410 (1984).

[14] W.F.J. Fontijn, P.J. van der Zaag, M.A.C. Devillers, V.A.M. Brabers, and R. Metselaar, Phys. Rev. B 56, 5432-5442 (1997).

[15] U. Kreibig and M. Vollmer, Optical Properties of Metal Clusters (Springer, Berlin, 1995).

[16] G.J. Babonas, A. Reza, I. Simkiene, J. Sabataityte, M. Baran, R. Szymczak, U.O. Karlsson, and A. Suchodolskis, Appl. Surf. Sci. 252, 5391-5394 (2006). 


\title{
GELEŽIES NANODALELIU SILICIO OKSIDE VALDOMAS FORMAVIMAS
}

\author{
I. Šimkiené ${ }^{a}$, G.J. Babonas ${ }^{a}$, A. Rėza ${ }^{a}$, M. Baran ${ }^{b}$, R. Szymczak $^{b}$, J. Sabataityte ${ }^{a}$, A. Suchodolskis ${ }^{\text {a }}$ \\ ${ }^{a}$ Puslaidininkiu fizikos institutas, Vilnius, Lietuva \\ ${ }^{\mathrm{b}}$ Lenkijos MA Fizikos institutas, Varšuva, Lenkija
}

\section{Santrauka}

$\mathrm{SiO}_{2}: \mathrm{Fe}$ sluoksniai ant $\mathrm{Si}$ padèklu buvo pagaminti, panaudojant zolio-gelio ir sukimo centrifūgoje metodikas. Buvo ruošiamas hibridinis tetraetoksisilano prekursorius, kurio sudètyje buvo $\mathrm{FeCl}_{3}$, arba organinis alkoksidinis prekursorius, modifikuotas geležies acetatu. Fe nanodalelès buvo formuojamos, panaudojant ivvairias technologines procedūras. Buvo tiriamos $\left(\mathrm{SiO}_{2}: \mathrm{Fe}\right) / \mathrm{Si}$ bandiniu sandaros, magnetinių ir optinių savybių priklausomybès nuo dariniu paruošimo technologijos. Parodyta, kad Fe nanodale- lių didumą galima valdyti prekursorių paruošimo procedūra. $\mathrm{Nu}-$ statyta, kad $\sim 40 \mathrm{~nm}$ vidutini didumą turinčios Fe nanodalelès susiformuoja tuomet, kai naudojama ,vieno indo“ metodika, ruošiant prekursorių iš Fe druskų ir šviežiai pagaminto koloidinio tetraetoksisilano (TEOS) tirpalų. Kita vertus, „dviejų indų“ metodikoje prekursoriaus sandai buvo ruošiami ne tuo pačiu metu ir panaudojamas struktūrizuoto TEOS zolis. Tokiu atveju Fe nanodaleliu didumai buvo išsidèstę platesniame intervale, bet vidutinè vertẻ $(\sim 25 \mathrm{~nm})$ buvo mažesnè. 